\title{
Immunohistochemical Localization of Benzodiazepine/GABA Receptors in the Human Hippocampal Formation
}

\author{
C. R. Houser, ${ }^{1}$ R. W. Olsen, ${ }^{2}$ J. G. Richards, ${ }^{3}$ and H. Möhler ${ }^{3}$ \\ ${ }^{1}$ Neurology Service, Veterans Administration Medical Center, West Los Angeles, Wadsworth Division, and Departments of \\ 'Anatomy and ${ }^{2}$ Pharmacology and the 1.2Brain Research Institute, University of California School of Medicine, Los \\ Angeles, California 90024, and ${ }^{3}$ Pharmaceutical Research Department, F. Hoffmann-La Roche and Co., CH-4002 Basel, \\ Switzerland
}

\begin{abstract}
Monoclonal antibodies to a purified benzodiazepine/GABA receptor complex from bovine cerebral cortex were used to determine the localization of this receptor in immunohistochemical preparations of the human hippocampal formation. The regional localization of the receptor was compared with the autoradiographic distribution of binding sites for a benzodiazepine antagonist, Ro 15-1788, and very similar patterns were observed. The highest levels of labeling were present in the molecular layer of the dentate gyrus, where much of the immunoreaction product was localized on the dendrites of granule cells. Lower levels of staining were observed in the granule cell layer, where reaction product was distributed around the perimeter of granule cell somata. The staining patterns varied among the different fields of the hippocampus. Labeling was lowest in the CA3 field, increased somewhat in the CA2 field, and was highest in the CA1 field. Within CA1, a laminar pattern was observed. Moderate to high levels of staining were present in strata oriens, pyramidale, radiatum, and moleculare, whereas less staining was observed in stratum lacunosum. The cellular localization of the receptor also differed among the hippocampal fields. Very little reaction product was observed on pyramidal neurons in the CA3 field, but labeling of pyramidal neurons appeared to increase progressively throughout CA2, CA1, and the subiculum. Nonpyramidal neurons were prominently labeled in all hippocampal fields. These results indicate that the benzodiazepine/GABA $A_{A}$ receptor is heterogeneously distributed among the different fields and on different neuronal cell types of the human hippocampus.
\end{abstract}

The locations of $\mathrm{GABA}_{\mathrm{A}}$ receptors, a subclass of GABA receptors defined by their sensitivity to the antagonist bicuculline, are of particular interest because these receptors appear to be the major type mediating inhibitory synaptic transmission in many brain regions (Bowery, 1983; Enna and Gallagher, 1983; Johnston et al., 1984; Roberts, 1986). It is now apparent that

\footnotetext{
Received May 4, 1987; revised Sept. 11, 1987; accepted Sept. 14, 1987

We gratefully acknowledge the assistance of the National Neurological Specimen Bank, directed by W. W. Tourtellotte, M.D., Ph.D., Veterans Administration Medical Center, West Los Angeles, California, in obtaining the human autopsy specimens. We also thank Janet Miyashiro and Irene Jones for their excellent technical assistance. This research was supported by VA Medical Research Funds and NIH Grants NS21908 and NS22071.

Correspondence should be addressed to Dr. C. R. Houser at the Brain Research Institute.

Copyright (C) 1988 Society for Neuroscience $0270-6474 / 88 / 041370-14 \$ 02.00 / 0$
}

benzodiazepine binding sites are associated with $\mathrm{GABA}_{\mathrm{A}}$ receptors and contribute to a receptor complex that also includes hinding sites for harbiturates (Costa and Guidotti, 1979; Olsen, 1982; Ticku and Maksay, 1983; Tallman and Gallager, 1985). By interacting with receptors of this complex, benzodiazepine and barbiturate ligands can enhance GABAergic neurotransmission, and may thereby produce many of their pharmacological effects (Study and Barker, 1981; Polc et al., 1982; Haefely and Polc, 1986). Immunohistochemical localization of these $\mathrm{GABA}_{\wedge}$ receptors is now possible using monoclonal antibodies to the receptor complex (Schoch et al., 1985; Richards et al., 1987), and the findings should complement those obtained by autoradiographic methods utilizing receptor ligands. Initial immunohistochemical studies have provided an overview of the cellular and subcellular receptor antigenic sites in several regions of the rat and human central nervous system (Schoch et al., 1985; Richards ct al., 1986, 1987), and more detailed studies of specific regions are now warranted.

The human hippocampal formation was selected for further study because of the functional importance of GABA in this brain region (Curtis et al., 1970; Barber and Saito, 1976; StormMathisen, 1977; Ribak et al., 1978; Alger and Nicoll, 1979; Andersen et al., 1980) and the need for a thorough understanding of the normal distribution of the benzodiazepine/GABA $A_{A}$ receptor in this part of the human brain prior to studying its localization in tissue from patients with temporal lobe epilepsy. The first goal of this study was to describe the regional distribution of the benzodiazepine/GABA ${ }_{A}$ receptors, utilizing monoclonal antibodies for immunohistochemical localization and the benzodiazepine antagonist Ro 15-1788 for autoradiographic localization. The second goal was to identify the types of hippocampal neurons that possess benzodiazepine/GABA $\mathrm{A}$ receptors and the regions of individual neurons where the receptors are located. A preliminary report of these findings has been published (Houser et al., 1986).

\section{Materials and Methods \\ Acquisition and preparation of tissue}

Autopsy specimens from the hippocampal formation of 4 unfixed brains were obtained from the Human Ncurological Specimen Bank, VA Wadsworth Medical Center, Los Angeles, CA. The subjects, one female and 3 males, had died at $48,57,63$, and 71 years of age and had no known history of neurological disease. Times between death and tissue processing (immersion in fixative solution or rapid freezing) ranged from 8 to $28 \mathrm{hr}$. As part of the neurospecimen bank's procedures, the brains were cut serially into $1-\mathrm{cm}$-thick coronal sections. Appropriate regions of the temporal lobe containing the hippocampal formation were iden- 
tified by the authors, removed from the larger sections, and resectioned to obtain 5-mm-thick blocks. Specimens to be used for immunohistochemistry were immersed in $4 \%$ paraformaldehyde in $0.12 \mathrm{M}$ phosphate buffer $(\mathrm{pH} 7.3)$. Small amounts of glutaraldehyde $(0.1-0.2 \%)$ were added to some of the fixative solutions. After 3-8 hr in fixative, the specimens were rinsed thoroughly in phosphate buffer. Following infiltration with a $20 \%$ sucrose solution, the specimens were frozen with dry ice, and $40-\mu \mathrm{m}$-thick coronal sections were cut on a cryostat (Reichert-Jung). Sections were rinsed in $0.1 \mathrm{M}$ Tris buffer $(\mathrm{pH} 7.4)$ and stored in serial order in the same buffer until immunohistochemical processing. Every tenth section was stained with cresyl violet for comparison with the immunohistochemical preparations. Specimens to be processed for àutoradiography were rapidly frozen between plates prechilled with liquid nitrogen. Tissue sections $(10 \mu \mathrm{m})$ were then cut on a cryostat and thaw-mounted onto chrome-alum/gelatin-coated microscope slides, as described by Palacios et al. (1981) and Wamsley et al. (1986), and stored at $-20^{\circ} \mathrm{C}$.

\section{Immunohistochemistry}

Monoclonal antibodies. Two monoclonal antibodies to the benzodiazepine/GABA receptor, bd-17 and bd-24 (Schoch et al., 1985), were used in this study. The preparation and characterization of these antibodies have been described previously (Häring et al., 1985; Schoch et al., 1985; Möhler et al., 1986). Briefly, mice were immunized with a purified benzodiazepine/GABA $\mathrm{A}_{\mathrm{A}}$ receptor preparation from bovine cerebral cortex, obtained by affinity-purification on a column of immobilized benzodiazepine (Schoch and Möhler, 1983). Hybridomas were produced by fusing spleen cells of the immunized mice with PAl myeloma cells, and the culture supernatants were screened for antibodies to the benzodiazepine/GABA ${ }_{A}$ receptor. Monoclonal antibodies bd- 17 and bd-24 were among 16 monoclonal antibodics sclected for further analysis. When culture supernatants containing either of the 2 antibodies were incubated with receptor samples, low- and high-affinity GABA binding sites, as well as flunitrazepam binding sites, were immunoprecipitated nearly completely (Schoch et al., 1985). Under appropriate experimental conditions, $t$-butylbicyclophosphorothionate (TBPS) binding sites associated with the chloride channel (Squires et al.,1983) were also coprecipitated (Möhler et al., 1986). Such findings suggest that these monoclonal antibodies are capable of immunoprecipitating the entire benzodiazepine receptor/GABA ${ }_{A}$ receptor/chloride channel complex. Neither of these antibodies interacts with the binding sites for benzodiazepines or the low- and high-affinity GABA sites of the purified receptor (Häring et al., 1985). Both antibodies are IgGs with $\gamma_{1}$ isotypes and recognize different subunits of the receptor. Bd-24 and bd-17 recognize epitopes on the $50 \mathrm{kDa}(\alpha)$ subunit and $55 \mathrm{kDa}(\beta)$ subunit, respectively. Both antibodies cross-react with the human receptor, whereas only bd-17 cross-reacts with the rat receptor (Häring et al., 1985).

Immunohistochemical incubations. Tissue from the hippocampal formation was processed for benzodiazepine/GABA $\mathrm{G}_{\mathrm{A}}$ receptor immunohistochemistry by the unlabeled antibody peroxidase-antiperoxidase (PAP) method (Sternberger, 1979), which has been used previously by the authors (Houser et al., 1985; Schoch et al., 1985; Richards et al., 1987). Free-floating sections were processed in continuously agitated solutions, and all incubations were performed at room temperature unless otherwise indicated. Prior to immunohistochemical processing, the sections were rinsed in a Tris-buffered saline solution (TBS; 0.1 M Tris buffer,

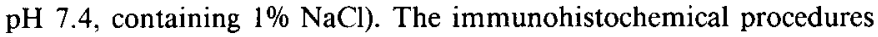
consisted of the following stcps:

1. Incubation in normal goat serum (diluted 1:30 in TBS containing $0.1-1.0 \%$ Triton X-100) for $1 \mathrm{hr}$. TBS containing $1.0 \%$ normal goat serum was used for diluting the remaining reagents.

2. Incubation in a hybridoma solution of bd-17 or bd-24 $(0.5-2 \mu \mathrm{g}$ $\mathrm{IgG} / \mathrm{ml}$ ) for $4 \mathrm{hr}$ at room temperature and for an additional $18 \mathrm{hr}$ at $4^{\circ} \mathrm{C}$. Control incubations omitted the primary antibody or substituted fetal calf serum for the primary antibody.

3. Incubation in goat anti-mouse IgG serum (American Qualex; diluted $1: 100$ ) for $1 \mathrm{hr}$.

4. Incubation in mouse monoclonal PAP complex (Sternberger Meyer Immunocytochemicals; diluted 1:100) for $1 \mathrm{hr}$.

Following each of the last 3 steps, the tissue was rinsed thoroughly in TBS. The sections were then reacted for $15 \mathrm{~min}$ with $0.006 \% 3,3^{\prime}$ diaminobenzidine $-\mathrm{HCl}$ and $0.006 \% \mathrm{H}_{2} \mathrm{O}_{2}$, diluted in $\mathrm{PBS}, \mathrm{pH} 7.3$. Sections were rinsed, treated for $30 \mathrm{sec}$ in $0.05 \%$ osmium tetroxide, rinsed again, and then mounted on slides. Sections were air-dried, dehydrated, and coverslipped.

\section{Autoradiography}

At the time of assay, the slide-mounted frozen, unfixed sections were thawed and preincubated in assay buffer $(0.17 \mathrm{M}$ Tris- $\mathrm{HCl}, \mathrm{pH} 7.4)$ at $0-4^{\circ} \mathrm{C}$ for $60 \mathrm{~min}$, with a buffer change at $30 \mathrm{~min}$. Binding of the benzodiazepine receptor antagonist ligand ${ }^{3} \mathrm{H}-\mathrm{Ro}$ 15-1788 $(71.4 \mathrm{Ci} /$ mmol; New England Nuclear, Boston, MA) was carried out for $60 \mathrm{~min}$ at $0-4^{\circ} \mathrm{C}$ in the same buffer containing one of 6 concentrations $(0.25-$ $10 \mathrm{~nm}$ ) of the radioactive ligand; nonspecific background was determined with parallel assays, including $1 \mu \mathrm{M}$ nonradioactive clonazepam.

The slides were rinsed twice for $1 \mathrm{~min}$ each at $0-4^{\circ} \mathrm{C}$ in nonradioactive buffer, briefly dipped into distilled water, dried with cold air, and stored overnight at $4^{\circ} \mathrm{C}$ with desiccant. They were then apposed to ${ }^{3} \mathrm{H}$-sensitive Ultrafilm (LKB Instruments, Rockville, MD) in x-ray cassettes and cxposed for $10-30 \mathrm{~d}$ at $4^{\circ} \mathrm{C}$. The optical densities were measured by computer-assisted microdensitometry (Zeiss IBAS), and quantitative radioactive ligand binding was determined from a standard curve produced from a series of ${ }^{3} \mathrm{H}$-embedded plastic microscales (Amersham, Arlington Heights, IL) corrected for tissue quenching (Amersham product information provided by $J$. Unnerstall). Each point (total or background) was the mean of at least 3 tissue sections for each anatomical subregion measured. The specific binding was plotted in the form of Scatchard plots (Fig. 3), from which the parameters $K_{\mathrm{d}}$ (affinity) and $B_{\max }$ (number of binding sites) were determined by linear regression.

\section{Results}

\section{Regional distribution}

Similar staining patterns were observed in immunohistochemical specimens prepared with either bd-17 or bd-24, as described previously for human tissue (Schoch et al., 1985; Richards et al., 1987). However, since slightly more detail was evident in the labeling obtained with bd-24, the antibody with the higher affinity, this antibody was used predominantly in the present study, and all photomicrographs are of specimens processed with bd-24. No specific staining was observed when fetal calf serum (the principal proteinaceous component of the hybridoma cell medium) was substituted for the primary antibody or when the primary antibody was omitted. Similar patterns of staining were observed within the hippocampal formations of all 4 cases studied. However, the neuronal morphology, when visualized at high magnification, was generally superior in the specimens with shorter postmortem intervals.

In low-magnification views of the immunohistochemical preparations, the highest intensity of staining was observed in the molecular layer of the dentate gyrus, whereas less reaction product was present in the hilus and granule cell layer (Fig. 1). In the hippocampus, the labeling patterns varied among the different fields. Labeling was lowest in the CA3 field, increased somewhat in the CA2 field, and was highest in the CA1 field (Fig. 1A). Within CA1, a laminar pattern was observed. Moderate to high levels of staining were present throughout strata oriens, pyramidale, and radiatum (Figs. $1 A, 2$ ). A narrow, more lightly stained band was present in stratum lacunosum, and the density of staining increased again in stratum moleculare to form a thin, stained lamina adjacent to the hippocampal fissure (Figs. 1,2 ). A subtle transition in the labeling patterns was observed at the $\mathrm{CAl} /$ subicular border. Moderate labeling was present throughout the pyramidal cell layers of the subiculum, but the lightly labeled band of stratum lacunosum and the dense labeling observed in stratum moleculare of the CA1 field were less evident (Fig. 1 $A$ ). Within the presubiculum, patches containing high concentrations of reaction product were irregularly distributed within the molecular layer. The relationship of these 
densely stained regions to neuronal aggregates in this layer will be described in a following section.

The autoradiographic localization of ${ }^{3} \mathrm{H}-\mathrm{Ro} 15-1788$ binding sites revealed a very similar labeling pattern to that of the immunohistochemical preparations (compare Fig. 1, $A$ and $B$ ). Computer-assisted densitometry of the autoradiographic data gave quantitative measures of ligand bound at various concentrations, and binding parameters for several areas were calculated from Scatchard plots (Fig. 3, Table 1). The results showed a consistent binding affinity $\left(K_{\mathrm{d}} 2.6-4.3 \mathrm{nM}\right)$ and variable densities of binding sites, ranging from $193 \mathrm{fmol} / \mathrm{mg}$ tissue in the hilus to $588 \mathrm{fmol} / \mathrm{mg}$ in the stratum moleculare of the dentate gyrus. In CA1, the density of binding sites was high, and the density in stratum moleculare was slightly greater than in stratum radiatum/pyramidale ( 521 versus $465 \mathrm{fmol} / \mathrm{mg}$ ). In the CA3 field, the density of benzodiazepine receptors in all layers was much lower than in CA1 (221 versus $465 \mathrm{fmol} / \mathrm{mg}$ in stratum radiatum/pyramidale).

\section{Cellular localization}

General characteristics. At high magnification, reaction product was visible on the membrane surface of individual neurons. Cytoplasmic labeling appeared light (Fig. $4 A$ ). In some instances, the staining along the surfaces of neuronal cell bodies and dendrites was periodic or punctate in appearance, as is evident on the nonpyramidal CAl neuron in Figure $4 B$. However, in some regions, the reaction product was distributed more diffusely, and could not be localized to specific cellular elements. For example, in the pyramidal cell layer of CA 1 , where the reaction product was quite concentrated, much of the product was distributed throughout the neuropil, and the labeled elements could not be identified (Fig. 4C). However, within this same region, light to moderate staining was also observed around the cell bodies of pyramidal neurons (Fig. $4 \mathrm{C}$ ). The cellular localization of reaction product within specific subregions of the hippocampal formation will be described in the following sections.

Dentate gyrus. The highest concentration of immunoreaction product in the hippocampal formation was observed in the molecular layer of the dentate gyrus. Most of the labeling within this layer appeared to be on the dendrites of granule cells (Fig. $5 A$ ). The somata of the granule cells were also outlined with reaction product, and, in some sections, the majority of the granule cell bodies appeared to be surrounded by reaction product (Fig. 5B). Labeling was also observed along the perimeter of axon initial segments of some granule cells. Virtually no staining was observed in the neuronal cytoplasm or nucleus (Fig. $5, A, B)$. In some specimens, the labeling along all of these neuronal surfaces was characterized by small, periodic concentrations of reaction product (Fig. $5 \mathrm{~A}$ ). In addition to the labeling of granule cells, hilar neurons adjacent to the granule cells were often outlined with reaction product (Fig. 5C). Labeling was present on the cell bodies of these neurons, as well as along their

Figure 1. Photomicrographs of autopsy specimens from the human hippocampal formation. $A$, Immunohistochemical localization of the benzodiazepine/GABA ${ }_{\mathrm{A}}$ receptor with monoclonal antibody bd- 24 . The highest densities of labeling are present in the molecular $(M)$ layer of the dentate gyrus, while the lowest densities are found in the hilus $(H)$ and CA3 field of the hippocampus. Moderate to high densities of staining are present in strata moleculare $(m)$, radiatum $(R)$, and pyramidale $(P)$
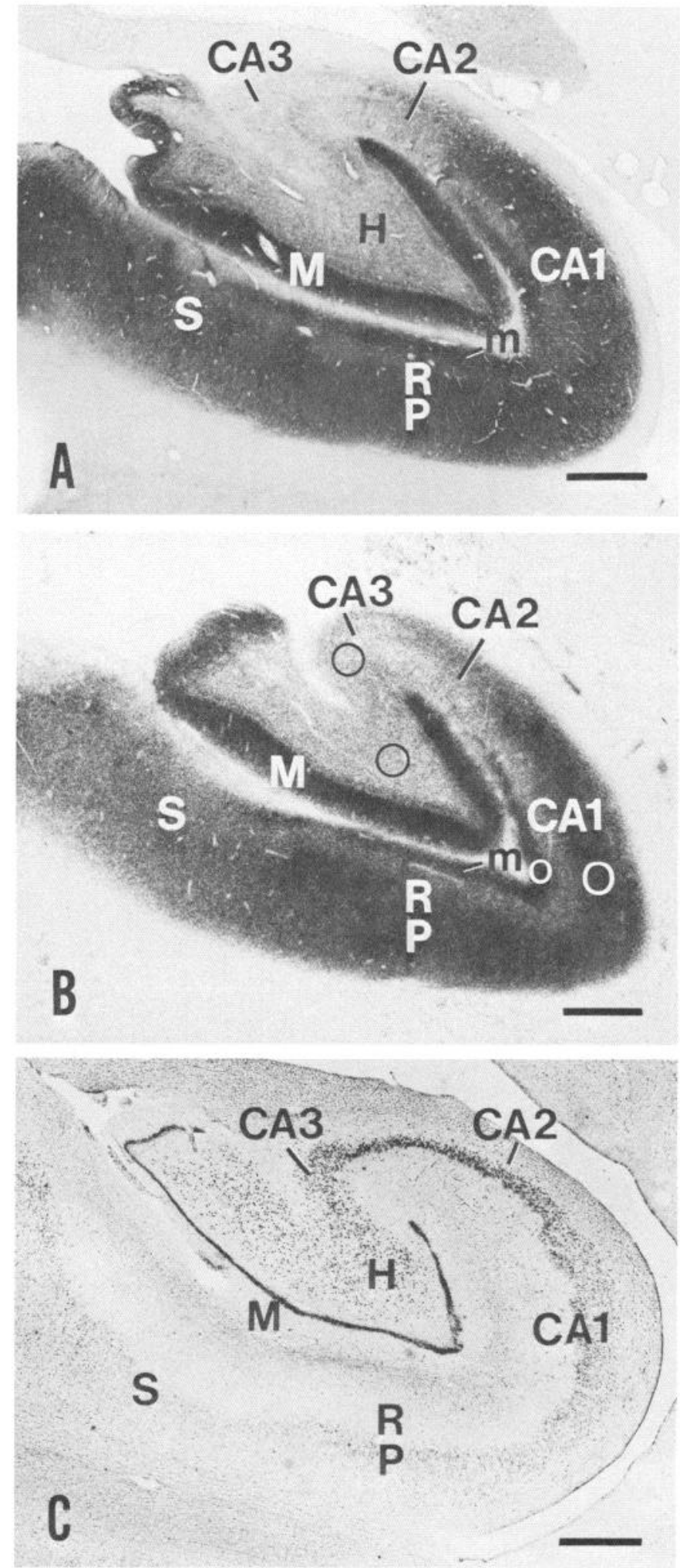

of the CA1 field, and moderate densities of staining continue into the subiculum $(S)$. B , Autoradiographic localization of ${ }^{3} \mathrm{H}-\mathrm{Ro} \quad 15-1788$ binding sites in an adjacent block of tissue (total binding, $1 \mu \mathrm{M}$ ). Labeling patterns are very similar to those of the immunohistochemical preparation. Regions selected for quantitative analysis are circled, and the data are presented in Table 1. $C$, Cresyl violet-stained specimen of the same region. Numerous neurons are present in the hilus $(H)$ and CA3 field, regions that show low densities of labeling in the above preparations. Scale lines, $1 \mathrm{~mm}$. 


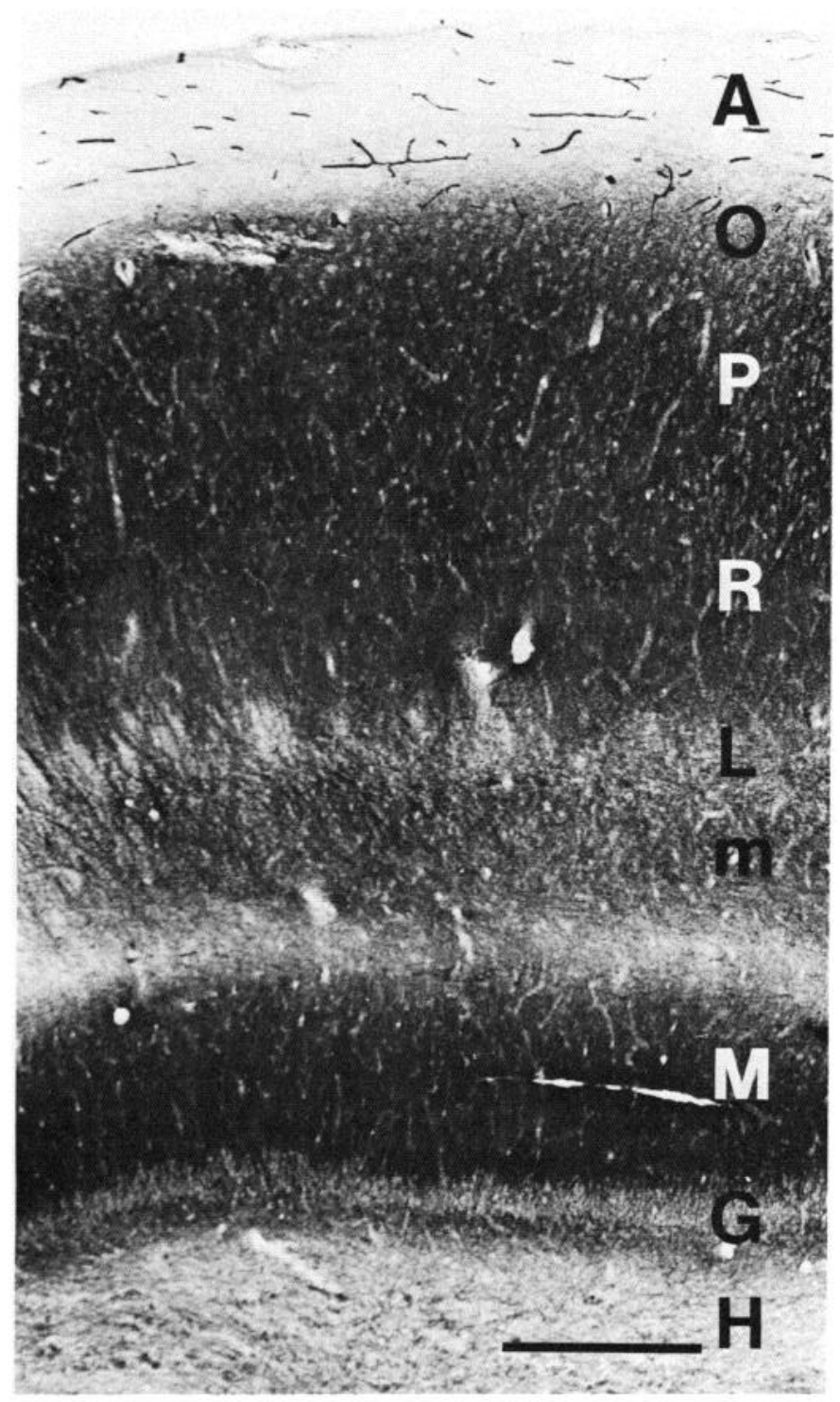

Figure 2. Laminar pattern of immunohistochemical staining in the dentate gyrus and CAl field of the hippocampal formation. The highest level of staining is found in the molecular $(M)$ layer of the dentate gyrus, and high levels of staining are also evident in the strata pyramidale $(P)$ and radiatum $(R)$ of the hippocampus. Moderate to high levels of staining are found in strata oriens $(O)$ and moleculare $(m)$ of the hippocampus, while lower levels of staining are present in stratum lacunosum $(L)$, stratum granulosum $(G)$, and the hilus $(H)$. Scale line, $500 \mu \mathrm{m}$.

dendrites, some of which extended horizontally immediately below the granule cell layer (Fig. 5C).

Hilus. Although low concentrations of reaction product were observed in the hilus at low magnification, a network of labeled dendrites and associated neuronal cell bodies was evident within this region when the sections were viewed at higher magnification (Fig. 6A). Many of the labeled neurons were multipolar and had large cell bodies (20-50 $\mu \mathrm{m}$ in diameter) and long dendrites, some of which extended as far as $700 \mu \mathrm{m}$ through the hilus in a single section (Fig. 6).

Hippocampal fields. The pattern of immunohistochemical labeling varied among the different hippocampal fields. The immunoreaction product was most concentrated in the CA1 field, diminished progressively through $\mathrm{CA} 2$, and reached the lowest

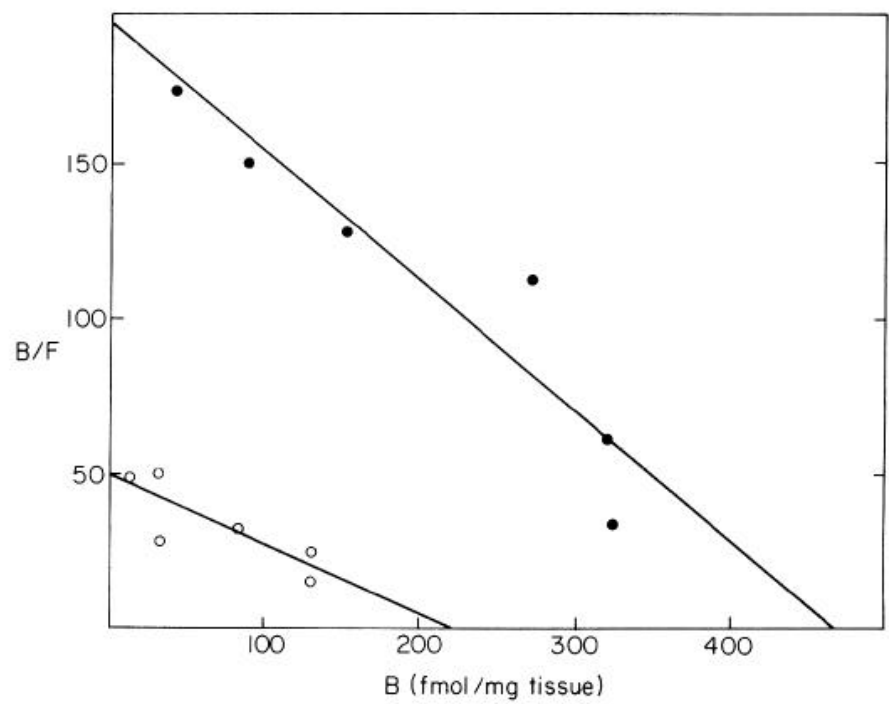

Figure 3. Scatchard plots of quantitative autoradiography measurements of ${ }^{3} \mathrm{H}$-Ro $15-1788$ binding to benzodiazepine receptors in regions of human hippocampal formation. Experimental details are given in Materials and Methods. Binding at 6 ligand concentrations, with and without cold clonazepam at $1 \mu \mathrm{M}$ to determine background, was measured in several regions, as indicated in Figure $1 B$. Two representative regions are depicted [stratum radiatum/pyramidale from CA1 $(\bullet)$ and $\mathrm{CA} 3(\mathrm{O})$, with linear correlation coefficients of 0.96 and 0.87]. Binding parameters from 5 regions are listed in Table 1.

levels in the CA3 field (Fig. 7). Within CA3, little labeling was observed on the cell bodies and processes of pyramidal neurons. Instead, the labeling appeared to be confined almost exclusively to nonpyramidal neurons. Reaction product outlined the cell bodies, as well as extensive lengths of many of the dendrites of these neurons (Fig. 8). Thus, it was possible to visualize the dendritic morphology of some of the labeled neurons. One type of nonpyramidal neuron that was frequently encountered was multipolar, with long dendrites that were oriented perpendicular to the pyramidal cell layer (Fig. 8A). The cell bodies of these neurons were located in strata pyramidale and radiatum and were generally oval or fusifom in shape. The dendrites that emerged from either end of the cell bodies extended for long distances through the CA3 laminae, and some of the dendritic trees appeared to span the distance from stratum moleculare to stratum oriens (Fig. 8A). Other nonpyramidal neurons with round to oval cell bodies and multipolar dendritic patterns were observed within the same layers (Fig. $8 B$ ). A third type of nonpyramidal neuron was observed in stratum oriens. These neurons exhibited horizontally oriented dendrites that extended for

Table 1. ${ }^{3} \mathrm{H}-\mathrm{Ro}$ 15-1788 binding autoradiography

\begin{tabular}{lll} 
Region & $K_{\mathrm{d}}(\mathrm{nM})$ & $\begin{array}{l}B_{\max } \\
\text { (fmol/mg } \\
\text { dry wt.) }\end{array}$ \\
\hline S. moleculare (dentate) & 2.6 & 588 \\
S. moleculare (CA1) & 2.9 & 521 \\
S. radiatum/pyramidale (CA1) & 2.4 & 465 \\
S. radiatum/pyramidale (CA3) & 4.3 & 221 \\
Hilus & 3.5 & 193 \\
\hline
\end{tabular}



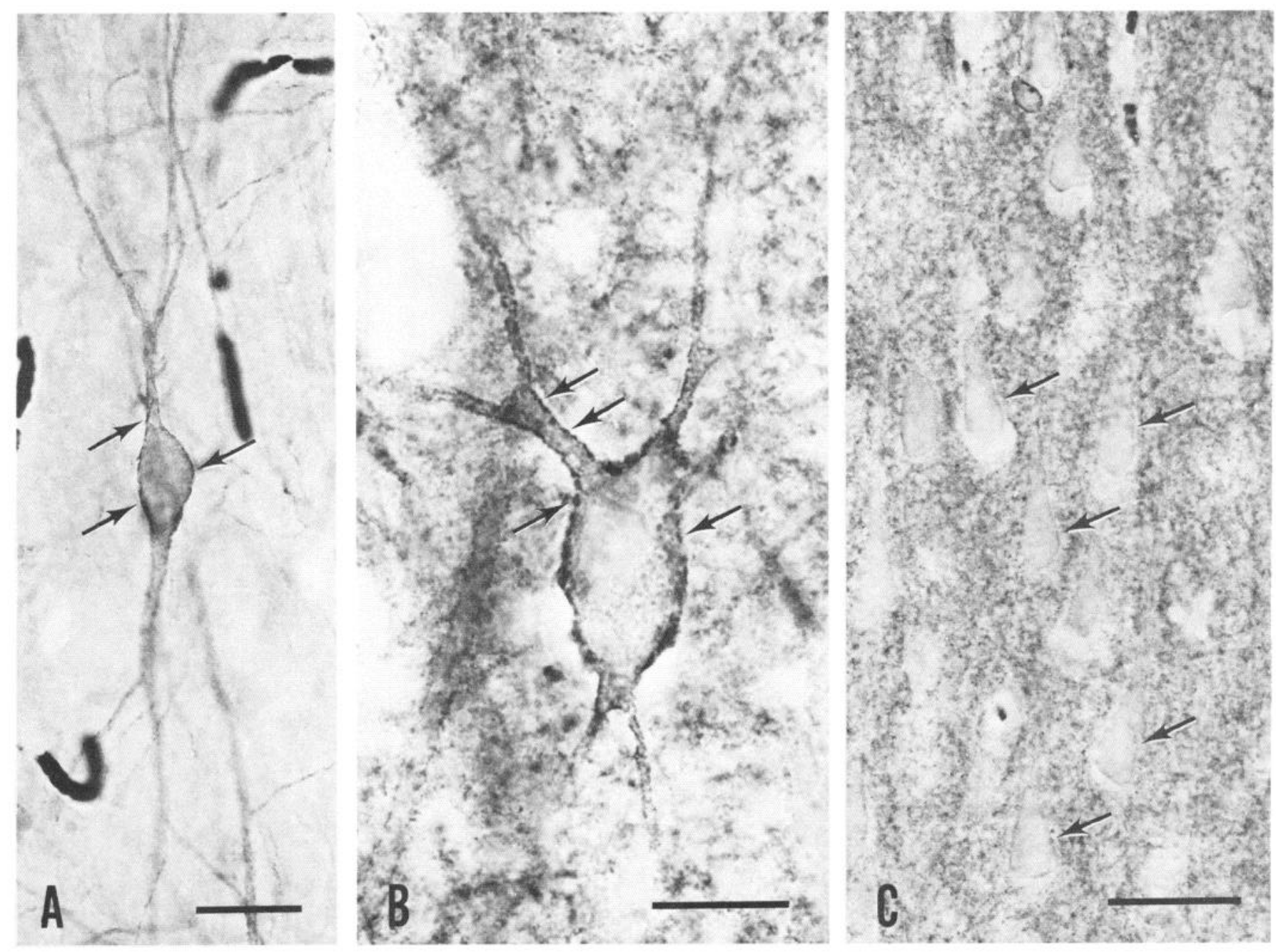

Figure 4. General characteristics of the cellular localization of benzodiazepine/GABA $\mathrm{A}_{\mathrm{A}}$ receptors in immunohistochemical preparations. A, Reaction product (arrows) is localized along the membrane surfaces of the cell body and dendritic processes of some neurons, such as this nonpyramidal neuron in the CA3 field. Scale line, $30 \mu \mathrm{m}$. B. At higher magnification, reaction product (arrows) can be visualized in a discontinuous distribution along the membrane surfaces of a nonpyramidal neuron in stratum pyramidale of the CAl field. Scale line, $20 \mu \mathrm{m}$. $C$, In regions such as the CA1 field, the reaction product is diffusely distributed throughout the neuropil, and the specific cellular localization of some labeling cannot be determined. However, small to moderate amounts of reaction product can be visualized around the cell bodies of pyramidal neurons (arrows) in this field. Scale line, $50 \mu \mathrm{m}$.

long distances and helped define the boundary between stratum oriens and the alveus (Fig. 9A). Similar labeled neurons with horizontally oriented dendrites were present in the other hippocampal fields (Fig. 9, B, C).

In $\mathrm{CA} 2$, the concentration of reaction product in strata pyramidale and radiatum was greater than in CA3. Reaction product was observed on presumptive apical dendrites of pyramidal neurons within stratum radiatum, and some of the labeled processes merged together to form fascicles, leaving adjacent regions relatively free of reaction product and creating a characteristic appearance in this field (Fig. 7). The ascending labeled processes appeared to bifurcate and diverge within stratum moleculare, and thus the immunoreactive elements were more evenly distributed within this layer (Fig. 7).

Within CA1, the density of labeled elements increased substantially, and moderately dense staining was observed throughout strata oriens, pyramidale, and radiatum (Figs. 1, 2, 7). Within these layers, reaction product appeared to be associated with several different types of neuronal elements. First, a large amount of reaction product was distributed diffusely throughout the neuropil, and it was difficult to identify the postsynaptic elements (Fig. 4C). In addition, reaction product was observed around the cell bodies of pyramidal neurons (Fig. 4C). Finally, reaction product was present around the perimeters of the cell bodies and dendrites of nonpyramidal neurons (Fig. $4 B$ ). In most regions, the concentration of reaction product around the cell bodies and proximal dendrites of nonpyramidal neurons generally appeared to be greater than that around the cell bodies of pyramidal neurons.

Subiculum. The pattern of staining within the subiculum had several unique features. First, apical dendrites of pyramidal neurons had a high density of reaction product along their surfaces (Fig. 10). Segments of several heavily labeled dendrites were often parallel to one another and formed bundles that could be visualized even at low magnification (Fig. 10, $A, B$ ). Another characteristic feature of the labeling in the subicular region was the presence of staining along the distal, branching portion of the apical dendrites (Fig. 10A), and these labeled elements cre- 

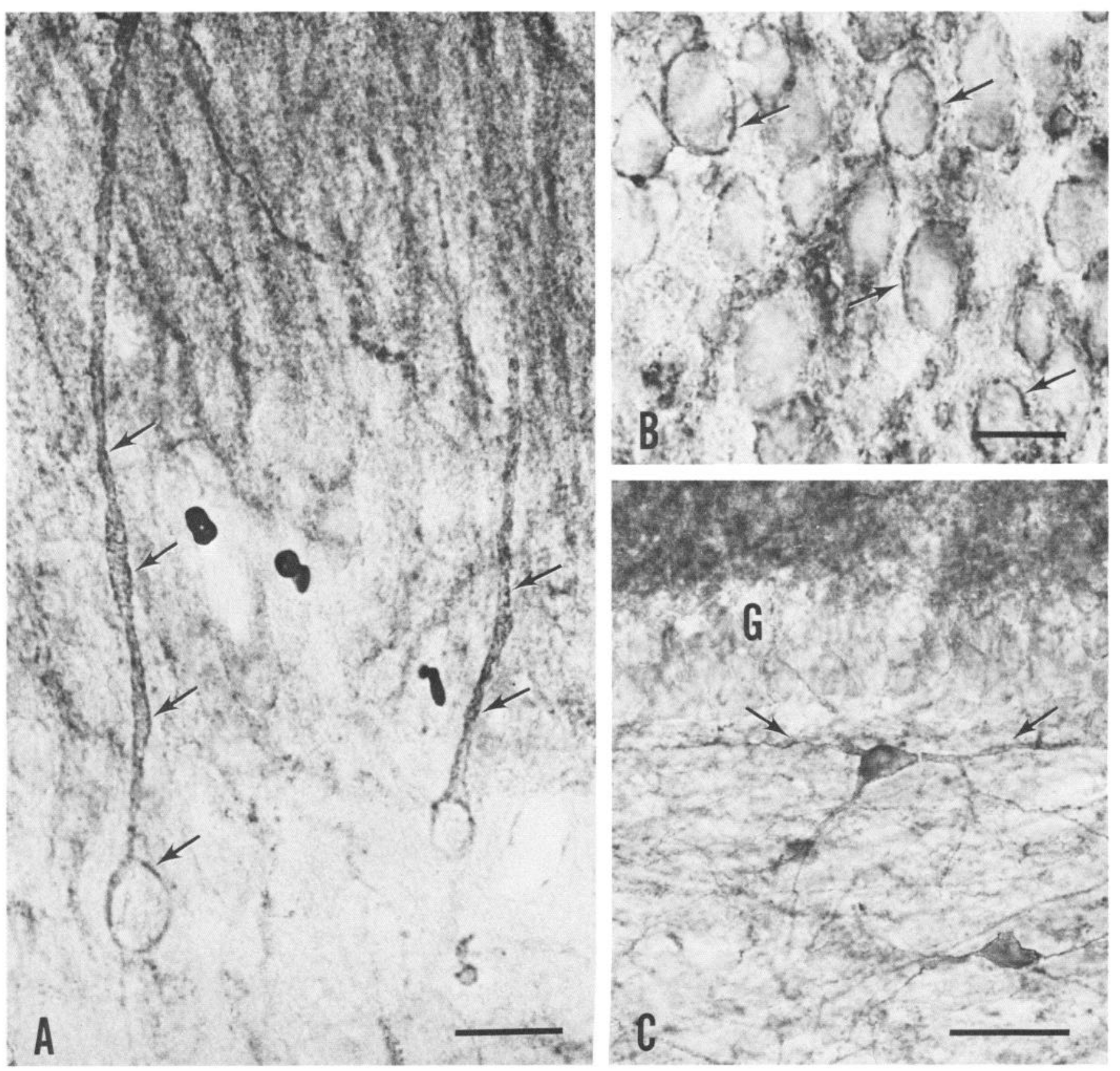

Figure 5. Localization of the benzodiazepine/GABA receptor in the dentate gyrus. $A$, Immunoreaction product (arrows) outlines the cell bodies and dendrites of granule cells in the dentate gyrus. Scale line, $20 \mu \mathrm{m}$. B. Within the granule cell layer, reaction product is evident on the surfaces of virtually all granule cell somata (arrows). The cytoplasm and nuclei of these neurons are relatively unstained. Scale line, $15 \mu \mathrm{m}$. $C$, A labeled neuron is present immediately below the stratum granulosum $(G)$. Dendrites (arrows) of the neuron extend horizontally just below the granule cells, while other dendritic processes branch within the hilus. Scale line, $50 \mu \mathrm{m}$.

ated a lacelike pattern in the outer layers of the subiculum. The cell bodies of many pyramidal neurons were also outlined by reaction product in the subicular region (Fig. 10C).

At the junction of the subiculum and presubiculum, islands of highly concentrated reaction product were distributed irregularly within the broad molecular layer (Fig. 11A). The density of labeled elements in these islands exceeded that in the deeper layers, as well as in nonisland regions of the molecular layer. Some of the islands were delineated by a thin, relatively unstained band around their superficial and lateral surfaces (Fig.
$11 A$ ). The locations of the densely stained patches corresponded closely to those of the islands or clouds of small neurons (Fig. $11 B$ ) that are characteristic of the molecular layer of the human presubiculum (Braak, 1980). However, comparisons with adjacent cresyl violet-stained sections demonstrated that the dense staining was not confined to the patches of cell bodies but extended beyond these regions to the pial surface (Fig. 11, $A, B$ ). Thus, the heavily stained regions appeared to encompass the groups of small cell bodies, as well as their dendrites, that extend through the molecular layer to the pia. 

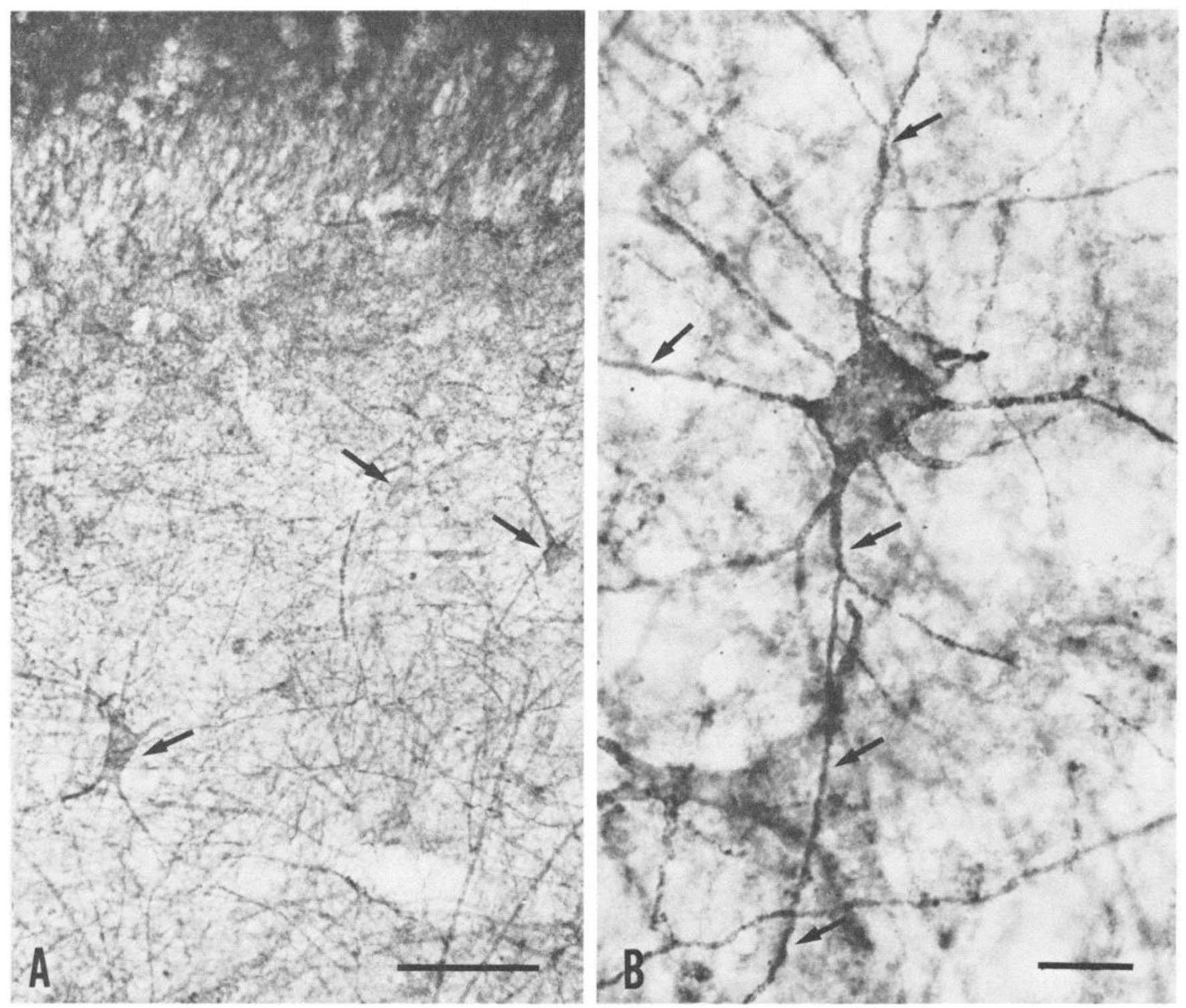

Figure 6. Immunohistochemical localization of the receptor within the hilus. A, Labeled neuronal cell bodies (arrows) and their dendritic processes form an extensive network within the hilus. Scale line, $100 \mu \mathrm{m}$. B, A large multipolar neuron is heavily labeled with reaction product, and the labeled dendrites (arrows) of this neuron extend for long distances through the hilus. Scale line, $25 \mu \mathrm{m}$.

\section{Discussion}

The general patterns of immunohistochemical labeling with 2 monoclonal antibodies to the benzodiazepine/ $\mathrm{GABA}_{\mathrm{A}}$ receptor protein and the pattern of autoradiographic localization of the benzodiazepine antagonist Ro 15-1788 were remarkably similar. The results obtained with the 2 methods did not simply duplicate each other, but, rather, provided complementary information on receptor localization, since the autoradiographic preparations permitted quantitative analysis of ligand binding and the immunohistochemical findings provided qualitative information on the cellular localization of the receptor.

The results of the present study confirm that the benzodiazepine/GABA ${ }_{\mathrm{A}}$ receptors are not homogeneously distributed throughout the human hippocampal formation. The distribution of the receptors varied not only among the different layers of the hippocampus and dentate gyrus, but also among the dif- ferent hippocampal fields and neuronal types. Laminar variations in receptor localization were particularly obvious in the fascia dentata and CA1 field, where receptor labeling was highly concentrated in "dendritic layers," such as the molecular layer of the dentate gyrus and the strata radiatum and moleculare of CA1. Qualitative study of both the autoradiographic and immunohistochemical findings, as well as quantitative analysis of the autoradiograms, indicated that the molecular layer of the dentate gyrus contained the highest density of benzodiazepine/ $\mathrm{GABA}_{\mathrm{A}}$ receptors in the human hippocampal formation. These findings are consistent with previous autoradiographic descriptions of high muscimol, GABA, and benzodiazepine binding in the molecular layer of human and rat dentate gyrus (Palacios et al., 1981; Penney et al., 1981; Marchon et al., 1985; Schoch et al., 1985; Wamsley et al., 1986; Bowery et al., 1987). The presence of benzodiazepine receptors in this layer is consonant with physiological demonstrations of benzodiazepine enhancement 


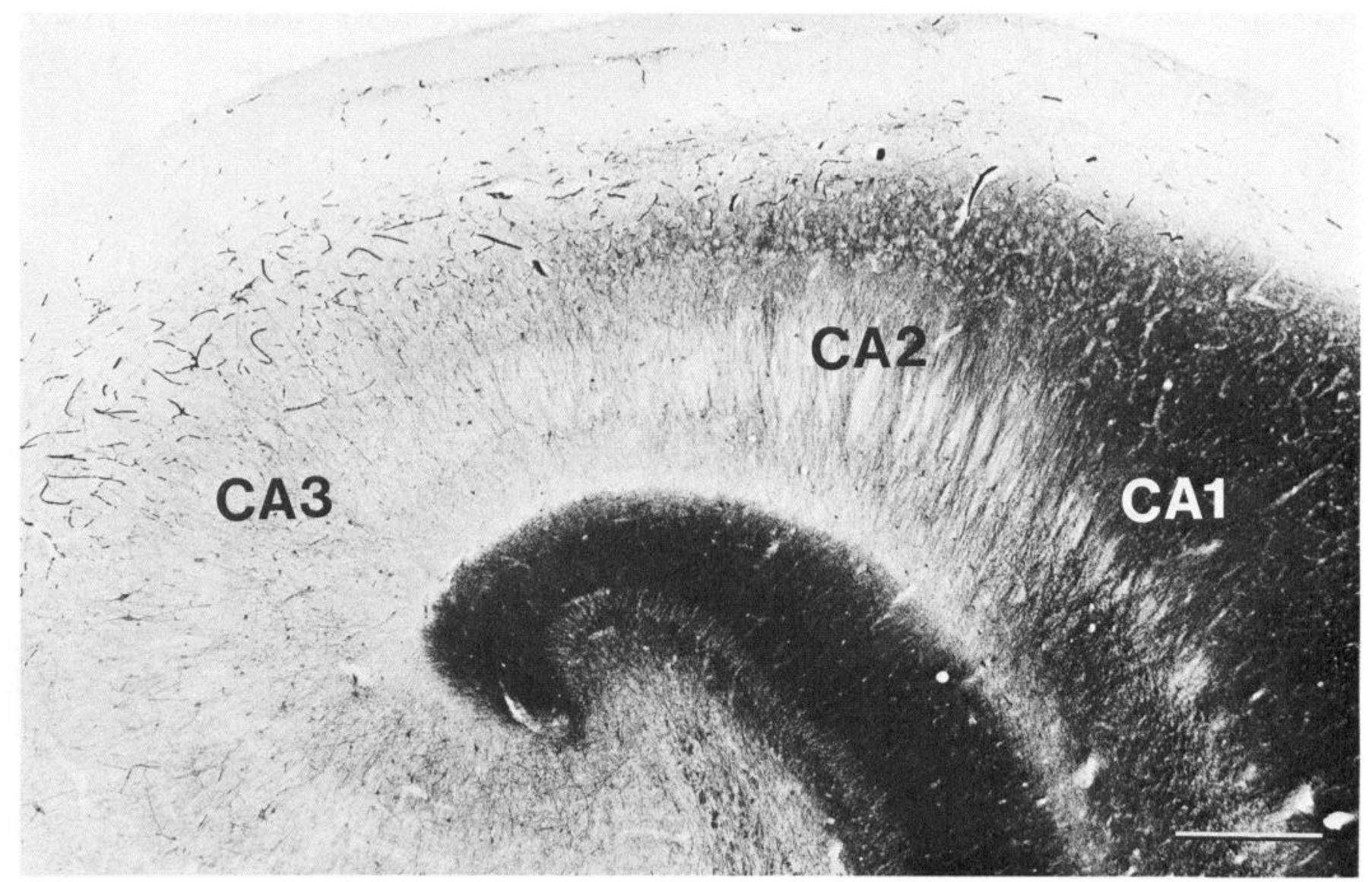

Figure 7. Immunohistochemical localization of the benzodiazepine/GABA $\mathrm{A}_{\mathrm{A}}$ receptor varies among the different fields of the human hippocampus. While low levels of labeling are evident in the CA3 field, moderate levels of labeling are found in the CA2 field, and much higher concentrations of reaction product are present in the CA1 field. Scale line, $500 \mu \mathrm{m}$.

in the molecular layer of the rat and mouse dentate gyrus (Jahnsen and Laursen, 1981; Alger and Nicoll, 1982; Biscoe and Duchen, 1985). Glutamic acid decarboxylase (GAD)- and GABA-containing terminals have also been demonstrated immunohistochemically in the molecular layer of both the human (Schlander et al., 1987) and rat (Barber and Saito, 1976; Seress and Ribak, 1983; Kosaka et al., 1984; Mugnaini and Oertel, 1985; Gamrani et al., 1986; Sloviter and Nilaver, 1987) dentate gyrus. Furthermore, in human tissue, GAD-containing terminals have been found on the same types of neuronal elements that exhibited receptor labeling in the present study, including dendritic shafts in the molecular layer and the somata of granule cells (Schlander et al., 1987). However, the degree of correspondence between the concentrations of GABA terminals and receptor labeling in the molecular layer of the human hippocampal formation is unknown.

In addition to laminar variations in the concentration of receptors in the dentate gyrus and CA1 field, a heterogeneous localization of benzodiazepine/GABA receptors was observed among the different hippocampal fields. This was one of the major, unexpected findings of the present study. While high densities of benzodiazepine/GABA receptors were present in the CA1 field and subiculum, much lower densities of these receptors were observed in $\mathrm{CA} 3$. Furthermore, the findings suggested that the varying densities of labeling in the different fields were due, in part, to differential localization on pyramidal neurons of these regions. While there appeared to be a relatively high concentration of the benzodiazepine/GABA $\mathrm{A}_{\mathrm{A}}$ receptors on the surfaces of pyramidal neurons in the subiculum and CA1 field, there was a virtual absence of receptor labeling on pyramidal neurons in the CA3 field, although there was receptor labeling of nonpyramidal neurons in this region.

Little attention has been focused on such regional differences in receptor localization within the human hippocampus, even though previously published autoradiograms of flunitrazepam and Ro 15-1788 binding suggested different densities of binding in the hippocampal fields (Manchon et al., 1985; Schoch et al., 1985; Richards et al., 1987). The immunohistochemical findings provide additional evidence that pyramidal neurons in the various hippocampal fields of the human may have different distributions of benzodiazepine/GABA receptors. These findings parallel some other aspects of hippocampal organization since it is known that neurons in the various hippocampal fields differ in their morphological features (Lorente de Nó, 1934; Braak, 1974), the source of some of their afferent fibers (Lorente de Nó, 1934; Cassell and Brown, 1984), and their susceptibilty to damage in various disease states (Rose, 1938; Meldrum and Corsellis, 1985). However, immunohistochemical studies of the rat hippocampus have demonstrated the presence of GAD- and GABA-containing terminals around the cell bodies of pyramidal neurons in all hippocampal fields (Barber and Saito, 1976; Mugnaini and Oertel, 1985; Sloviter and Nilaver, 1987). Thus, the presence of very low amounts of benzodiazepine/GABA $\mathrm{A}_{\mathrm{A}}$ receptor labeling on pyramidal neurons in the CA3 field of the 

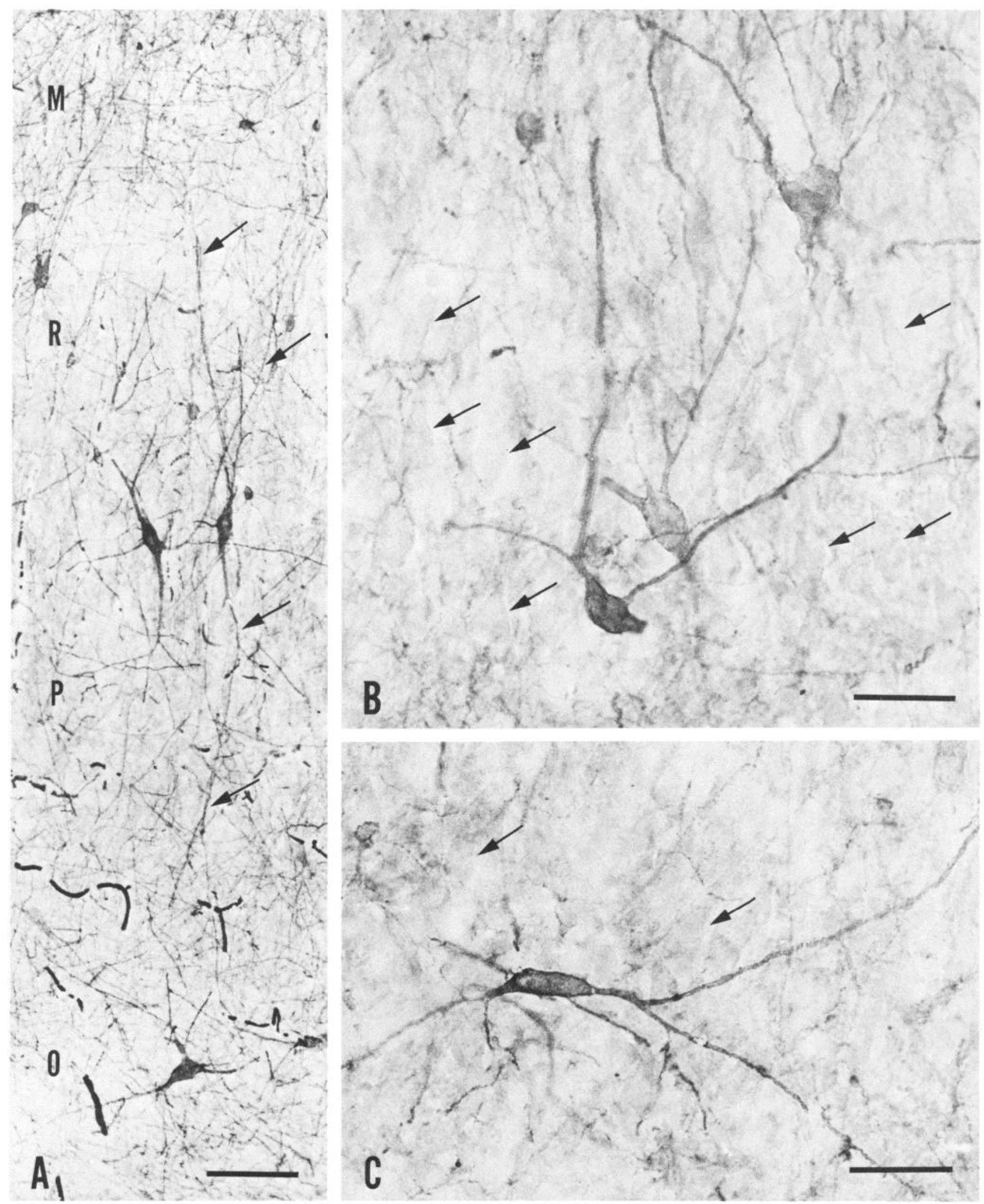

Figure 8. Immunohistochemical localization of the benzodiazepine/GABA receptor in the CA3 field. $A$, Receptor labeling is prominent on the surfaces of nonpyramidal neurons within this field. Some of the neurons are vertically oriented, and labeled dendrites (arrows) extend for long distances within this field. s. moleculare, $M$; s. radiatum, $R$; s. pyramidale, $P$; s. oriens, $O$. Scale line, $100 \mu \mathrm{m}$. $B, C$, Multipolar neurons are readily visualized within the stratum pyramidale of the $C A 3$ field because of the receptor labeling around their somata and dendrites. In contrast, surrounding pyramidal neurons (arrows) are virtually unlabeled. Scale lines, $25 \mu \mathrm{m}(B) ; 50 \mu \mathrm{m}(C)$. 

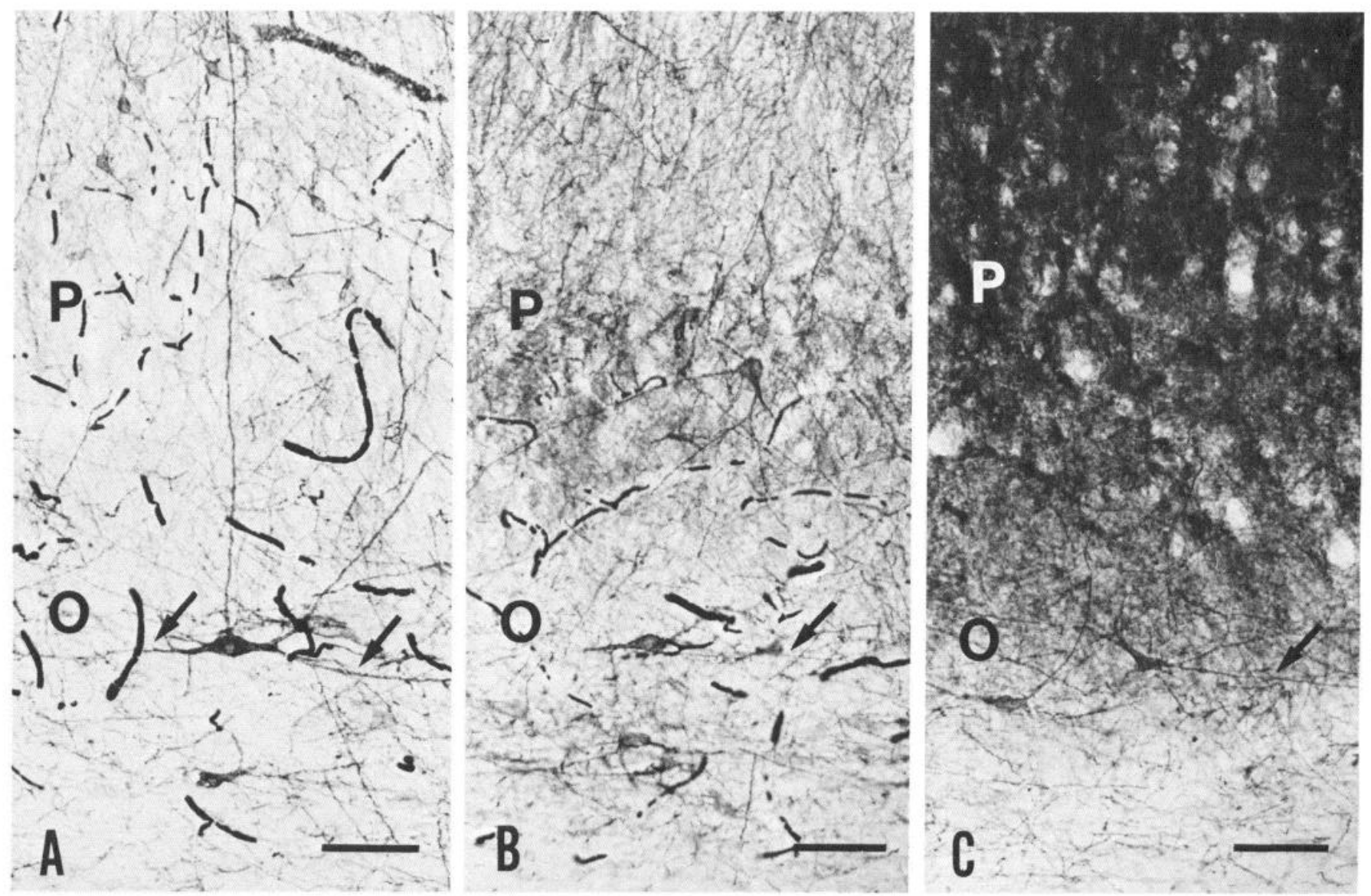

Figure 9. Labeled nonpyramidal neurons are evident in stratum oriens $(O)$ of all hippocampal fields, and many display long, horizontally oriented dendrites (arrows). As illustrated previously, the general staining pattern in stratum pyramidale $(P)$ changes from very little labeling in the CA3 field $(A)$ to moderate concentrations of reaction product in the CA2 field $(B)$ and, finally, to high concentrations in the CA1 field $(C)$. Scale lines, $100 \mu \mathrm{m}$.

human hippocampus is intriguing, and several explanations might be considered.

Technical factors that could have influenced the localization patterns and contributed to the differential labeling in the hippocampal fields were evaluated first. The condition of the tissue was of prime concern, since varying degrees of autolysis are inevitably present in human postmortem tissue. However, binding of receptor ligands is quite resistant to postmortem change (Lloyd and Dreksler, 1979). In addition, the distinct patterns of ligand binding in the autoradiograms and the cellular detail observed in the immunocytochemical preparations of the present study suggest that the tissue was adequately preserved for accurate histological localization of the receptor. Furthermore, the differential patterns of labeling in the hippocampal fields do not appear to be related to postmortem changes, since similar patterns of immunocytochemical staining were observed in all cases despite differing postmortem intervals before tissue processing. Furthermore, cresyl violet-stained sections revealed a normal histological appearance of the hippocampal formation, and no field appeared to be preferentially affected by postmortem changes.

However, there are normal histological differences among the hippocampal fields that could potentially contribute to the different staining patterns. For example, CA1 pyramidal neurons are smaller than those of CA3 and, therefore, in a section of a given thickness, more cells and processes might be stained in
CA1, giving a generally darker appearance, even though the amount of antibody bound per unit of membrane might be the same. However, it seems unlikely that such differences in the density of neuronal elements could account for the large (50\%) difference observed in ligand binding between the $\mathrm{CA} 1$ and $\mathrm{CA} 3$ fields. Furthermore, with the high resolution obtained in the immunocytochemical preparations, it was possible to visualize many neuronal cell bodies in the CA3 field that displayed virtually no reaction product on their surfaces. This suggests that the differences in staining were not entirely due to different concentrations of stained elements. Thus, other explanations for the observed staining patterns must be considered.

One possibility is that the conformation of the receptor in the CA3 field differs from that in CA1, and, as a result, the epitopes recognized by the present monoclonal antibodies were not exposed in the CA3 field. However, lower densities of labeling were also observed in the CA3 region by autoradiographic methods. Thus, it seems highly unlikely that a conformational change of the receptor in the CA3 field could account for an "artifactual" lack of labeling in specimens prepared with several different benzodiazepine and $\mathrm{GABA}_{\mathrm{A}}$ receptor ligands, as well as 2 monoclonal antibodies that recognize different epitopes and subunits of the benzodiazepine/GABA $\mathrm{A}_{\mathrm{A}}$ receptor complex. Another explanation could be that the variations in the densities of the benzodiazepine/GABA ${ }_{A}$ receptor are associated with differences in the GABAergic innervation of the hippocampal fields. Al- 

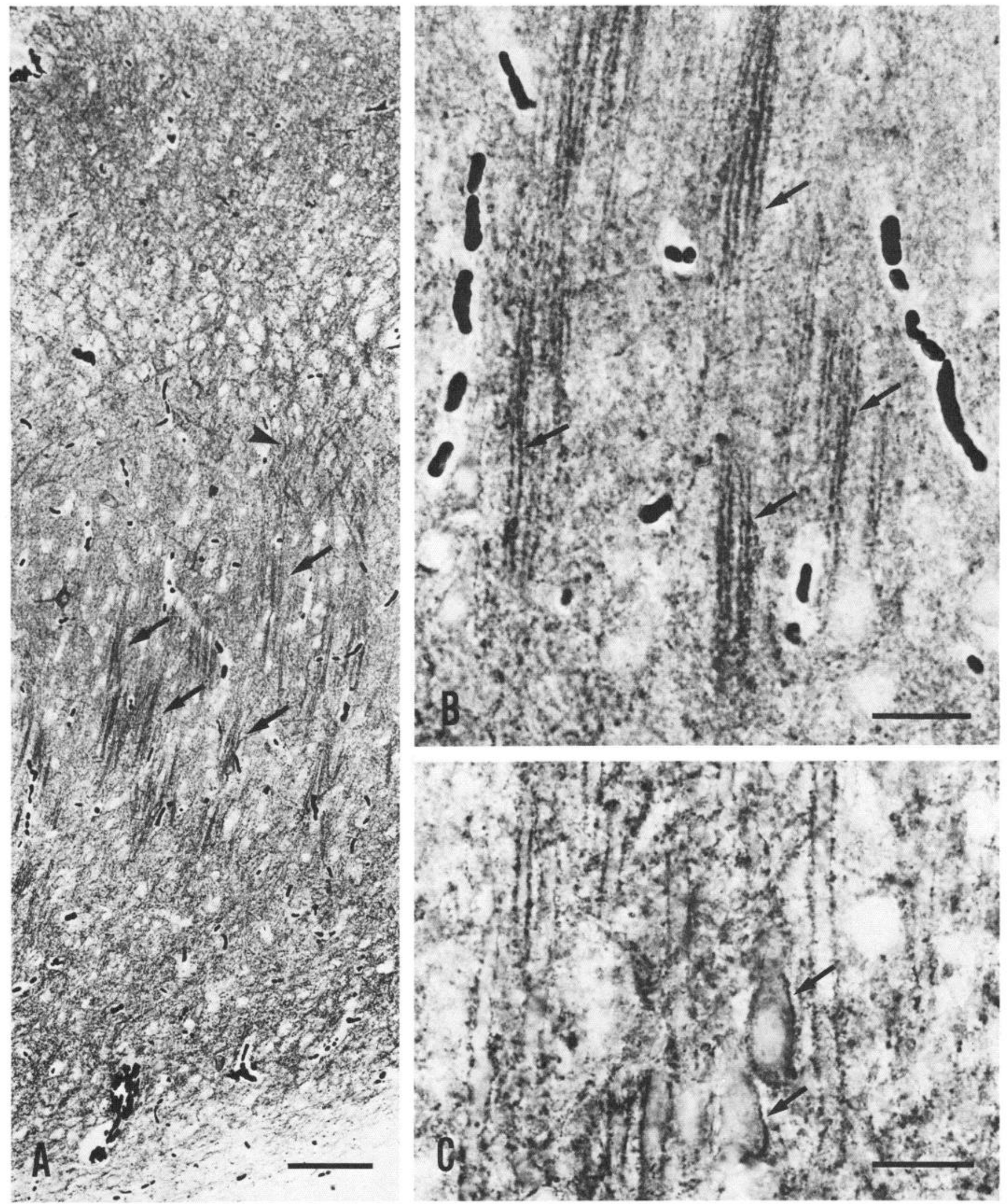

Figure 10. Immunohistochemical localization of the receptor in the subiculum. A, A distinctive staining pattern is present in the subiculum and includes heavy labeling of groups of vertically oriented dendrites (arrows), as well as labeling of small-diameter dendrites that form a latticelike pattern (arrowhead) within the superficial layers. Scale line, $100 \mu \mathrm{m}$. B. At higher magnification, the punctate nature of the receptor labeling (arrows) is evident along the presumptive apical dendrites of pyramidal neurons. Scale line, $20 \mu \mathrm{m}$. $C$, Reaction product can be visualized on the surfaces of cell bodies of pyramidal neurons (arrows) in this region. Scale line, $25 \mu \mathrm{m}$. 

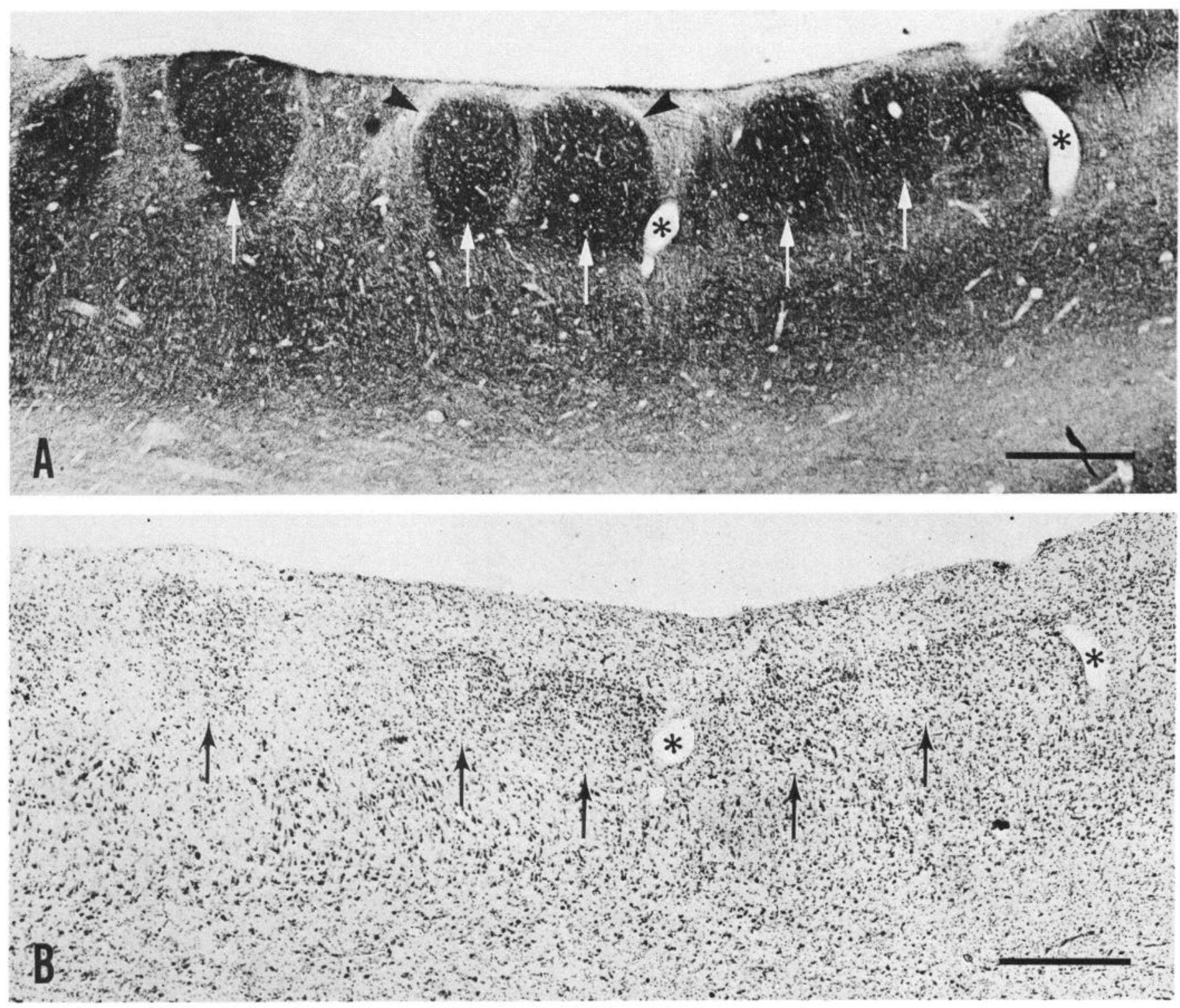

Figure 11. Immunohistochemical and cresyl violet-stained sections of the presubiculum. $A$, Immunoreaction product is most highly concentrated in patches within the thick molecular layer of this cortical region. The islands of dense staining (arrows) often extend nearly to the pial surface and are sometimes surrounded on their outer and lateral surfaces by a relatively unstained capsule of presumptive fibers (arrowheads). B, In an adjacent cresyl violet-stained section, islands of small neurons (arrows) are distributed irregularly within the molecular layer. The locations of these neuronal groups correspond closely to the patches of dense receptor labeling illustrated in $A$. However, the immunolabeling extends beyond the region of the cell bodies and approaches the pial surface. Asterisks mark the same blood vessels in both specimens. Scale lines, $500 \mu \mathrm{m}$.

though differences in the concentration of GAD- and GABAcontaining terminals among the various fields have not been noted in the rat (Barber and Saito, 1976; Mugnaini and Oertel, 1985), they cannot be ruled out in the human hippocampus, since species differences in the distribution and organization of GABA terminals could exist.

The localization pattern of benzodiazepine/GABA receptors in the human hippocampal formation does, in fact, differ in several respects from that observed in the rat (Richards et al., 1987). Although immunolabeling of the receptor was virtually absent from pyramidal neurons and their processes within the CA3 field of the human hippocampus, such labeling increased within the $\mathrm{CA} 2$ field and reached relatively high densities within both the strata pyramidale and radiatum of the CAl field. However, in the rat, little staining was observed around the cell bodies of pyramidal neurons in stratum pyramidale of all hip- pocampal fields (Richards et al., 1987). Furthermore, substantial labeling was seen in the stratum radiatum of all fields, although there appeared to be a decrease in labeling within the CA2-CA3 fields as compared with that of the CA1 field. The receptor localization within the subiculum also appeared to differ in the rat and human. Whereas a marked decrease in the density of receptor labeling was observed at the $\mathrm{CAl} /$ subicular border in the rat (Richards et al., 1987), such a change was not observed in the human tissue. Furthermore, the islands of dense staining in the presubicular region have, thus far, only been found in human tissue, where the islands of small cells with which they are associated are particularly evident (Braak, 1980). These differences in the localization of the benzodiazepine/GABA $\mathrm{A}_{\mathrm{A}}$ receptor suggest that there could be other species differences in the organization of the GABA system within the hippocampal formation. 
Another possible explanation for the varying patterns of localization in the different hippocampal fields is that the type of GABA receptor might differ among the various fields. Although there is substantial evidence that $\mathrm{GABA}_{\mathrm{A}}$ receptors are frequently associated with benzodiazepine receptors within the receptor complex, it is possible that a subclass of $\mathrm{GABA}_{\mathrm{A}}$ receptors lacking the benzodiazepine receptor could exist (Unncrstall ct al., 1981; Olsen ct al., 1984). Such a GABA receptor might not be detected with either of the antibodies used in this study and would not be identified by the autoradiographic localization of benzodiazepine binding sites. Furthermore, a lowaffinity $\mathrm{GABA}_{\mathrm{A}}$ receptor of this type might also be distinct from the high-affinity GABA binding sites labeled by ${ }^{3} \mathrm{H}-\mathrm{muscimol}$. Immunohistochemical studies of GABA terminals and autoradiographic studies of other $\mathrm{GABA}_{\mathrm{A}}$ receptor ligands, such as TBPS and bicuculline, and $\mathrm{GABA}_{\mathrm{B}}$ receptor ligands in human hippocampus; should provide the information necessary for determining which of the last 2 explanations is more likely.

Finally, in the human hippocampal formation, there appear to be variations in the density of benzodiazepine/GABA $\mathrm{Ge}$ ceptors on different neuronal cell types. A prominent immunohistochemical localization of the benzodiazepine/GABA $A_{A}$ receptor on nonpyramidal neurons was particularly striking. In some regions of the hippocampal formation, such as the hilus and CA3 field, many nonpypramidal neurons appeared to be labeled preferentially. In these regions, the labeling produced an outline of much of the neuronal surface, extending around the cell body and along the perimeter of the dendrites. These labeled neurons were particularly easy to visualize in the hilus and CA 3 field, since many surrounding neurons, including pyramidal neurons, were virtually unlabeled. Even within the CA1 field, the labeling appeared to outline nonpyramidal neurons more distinctly than pyramidal cell processes within the same field. Such observations invite speculation that a particular functional class of neurons may possess a higher density of benzodiazepine/GABA $\mathrm{G}_{\mathrm{A}}$ receptors than other neurons, and doublelabeling studies are needed to determine the chemical identity of the receptor-rich neurons. The general morphological characteristics and locations of these neurons are similar to those of GABA neurons, as described in other species (Ribak et al., 1978; Seress and Ribak, 1983; Schmechel et al., 1984; Kosaka et al., 1985; Mugnaini and Oertel, 1985; Gamrani et al., 1986; Sloviter and Nilaver, 1987), and recently identified in human tissue (Schlander et al., 1987). Furthermore, physiological and anatomical evidence suggests that some GABA-containing neurons in the hilus receive a GABAergic innervation (Misgeld and Frotscher, 1986; Schlander et al., 1987) and thus would bc cxpected to possess GABA receptors. However, other nonpyramidal neurons in the human hippocampus are also candidates for the receptor-rich group of neurons.

The present findings suggest that there are differences in the organization of the GABA system among the hippocampal fields. Such differences could have important functional consequences, since they could lead to differences in the electrical properties of the fields, and could be critical for our understanding of disease processes such as temporal lobe epilepsy, in which some regions of the hippocampus may be preferentially affected. However, both pre- and postsynaptic elements are necessary for function, and only one component of the GABA system was examined in the present study. The findings must now be related to the locations of GABA terminals and other subtypes of GABA receptors in order to obtain a more comprehensive view of the organization of the GABA system in the human hippocampal formation.

\section{References}

Alger, B. E., and R. A. Nicoll (1979) GABA-mediated biphasic inhibitory responses in hippocampus. Nature $281: 315-317$.

Alger, B. E., and R. A. Nicoll (1982) Feed-forward dendritic inhibition in rat hippocampal pyramidal cells studied in vitro. J. Physiol. (Lond.) 328: $105-123$.

Andersen, P., R. Dingledine, L. Gjerstad, I. A. Langmoen, and A. Mosefeldt Laursen (1980) Two different responses of hippocampal pyramidal cells to application of gamma-amino butyric acid. J. Physiol. (Lond.) 305: 279-296.

Barber, R., and K. Saito (1976) Light microscopic visualization of GAD and GABA-T in immunocytochemical preparations of rodent CNS. In GABA in Nervous System Function. E. Roberts, T. N. Chase, and D. B. Tower, eds., pp. 113-132, Raven, New York.

Biscoe, T. J., and M. R. Duchen (1985) Actions and interactions of GABA and benzodiazepines in the mouse hippocampal slice. Q. J. Exp. Physiol. 70: 313-328.

Bowery, N. G. (1983) Classification of GABA receptors. In The GABA Receptors, S. J. Enna, ed., pp. 177-213, Humana, Clifton, NJ.

Bowery, N. G., A. L. Hudson, and G. W. Price (1987) GABA $_{A}$ and $\mathrm{GABA}_{B}$ receptor site distribution in the rat central nervous system. Neuroscience 20: 365-383.

Braak, H. (1974) On the structure of the human archicortex. Cell Tissue Res. 152: 349-383.

Braak, H. (1980) Architectonics of the Human Telencephalic Cortex, Springer-Verlag, New York.

Cassell, M. D., and M. W. Brown (1984) The distribution of Timm's stain in the nonsulphide-perfused human hippocampal formation. J. Comp. Neurol. 222: 461-471.

Costa, E., and A. Guidotti (1979) Molecular mechanisms in the receptor action of benzodiazepines. Annu. Rev. Pharmacol. Toxicol. 19: 531-545.

Curtis, D. R., D. Felix, and H. McLennan (1970) GABA and hippocampal inhibition. Br. J. Pharmacol. 40: 881-883.

Enna, S. J., and J. P. Gallagher (1983) Biochemical and electrophysiological characteristics of mammalian GABA receptors. Int. Rev. Neurobiol. 24: 181-212.

Gamrani, H., B. Onteniente, P. Seguela, M. Geffard, and A. Calas (1986) Gamma-aminobutyric acid-immunoreactivity in the rat hippocampus. A light and electron microscope study with anti-GABA antibodies. Brain Res. 364: 30-38.

Haefely, W., and P. Polc (1986) Physiology of GABA enhancement by benzodiazepines and barbiturates. In Benzodiazepine/GABA Receptors and Chloride Channels, Structural and Functional Properties, R. W. Olsen and J. C. Venter, eds., pp. 97-133, Liss, New York.

Häring, P., C. Stähli, P. Schoch, B. Takács, T. Staehelin, and H. Möhler (1985) Monoclonal antibodics revcal structural homogeneity of $\gamma$-aminobutyric acid/benzodiazepine receptors in different brain areas. Proc. Natl. Acad. Sci. USA 82: 4837-4841.

Houser, C. R., G. D. Crawford, P. M. Salvaterra, and J. E. Vaughn (1985) Immunocytochemical localization of choline acetyltransferase in rat cerebral cortex: A study of cholinergic neurons and synapses. J. Comp. Neurol. 234: 17-34.

Houser, C. R., R. W. Olsen, J. G. Richards, and H. Möhler (1986) Immunocytochemical localization of a GABA $A_{A}$ benzodiazepine receptor complex in the human hippocampal formation. Soc. Neurosci. Abstr. 12: 1386.

Jahnsen, H., and A. Laursen (1981) The effects of a benzodiazepine on the hyperpolarizing and the depolarizing responses of hippocampal cells to GABA. Brain Res. 207: 214-217.

Johnston, G. A. R., R. D. Allan, and J. H. Skcrritt (1984) GABA receptors. In Handbook of Neurochemistry, vol. 6, A. Lajtha, ed., pp. 213-237, Plenum, New York.

Kosaka, T., K. Hami, and J.-Y. Wu (1984) GABAergic synaptic boutons in the granule cell layer of the rat dentate gyrus. Brain Res. 293: 353-359.

Kosaka, T., K. Kosaka, K. Tateishi, Y. Hamaoka, N. Yanaihara, J.-Y. Wu, and K. Hama (1985) GABAergic neurons containing CCK-8like and/or VIP-like immunoreactivities in the rat hippocampus and dentate gyrus. J. Comp. Neurol. 239: 420-430.

Lloyd, K. G., and S. Dreksler (1979) An analysis of $\left[{ }^{3} \mathrm{H}\right]$ gamma- 
aminobutyric acid (GABA) binding in the human brain. Brain Res. 163: 77-87.

Lorente de Nó, R. (1934) Studies on the structure of the cerebral cortex. II. Continuation of the study of the ammonic system. J. Psychol. Neurol. (Leipzig) 46: 113-177.

Manchon, M., N. Kopp, P. Bobillier, and S. Miachon (1985) Autoradiographic and quantitative study of benzodiazepine-binding sites in human hippocampus. Neurosci. Lett. 62: 25-30.

Meldrum, B. S., and J. A. N. Corsellis (1985) Epilepsy. In Greenfield's Neuropathology, 4th Ed., pp. 921-950, Wiley, New York.

Misgeld, U., and M. Frotscher (1986) Postsynaptic-GABAergic inhibition of non-pyramidal neurons in the guinea-pig hippocampus. Neuroscience 19: 193-206.

Möhler, H., P. Schoch, J. G. Richards, P. Häring, B. Takács, and C. Stähli (1986) Monoclonal antibodies: Probes for structure and location of the GABA receptor/benzodiazepine receptor/chloride channel complex. In Benzodiazepine/GABA Receptors and Chloride Channels: Structural and Functional Properties, R. W. Olsen and J. C. Venter, eds., pp. 285-297, Liss, New York.

Mugnaini, E., and W. H. Oertel (1985) An atlas of the distribution of GABAergic neurons and terminals in the rat CNS as revealed by GAD immunohistochemistry. In Handbook of Chemical Neuroanatomy, vol. 4: GABA and Neuropeptides in the CNS, pt. 1, A. Björklund and T. Hökfelt, eds.,pp. 436-622, Elsevier, New York.

Olsen, R. W. (1982) Drug interactions at the GABA receptor ionophore complex. Annu. Rev. Pharmacol. Toxicol. 22: 245-277.

Olsen, R. W., E. W. Snowhill, and J. K. Wamsley (1984) Autoradiographic localization of low affinity GABA receptors with $\left[{ }^{3} \mathrm{H}\right]$ bicuculline methochloride. Eur. J. Pharmacol. 99: 247-248.

Palacios, J. M., J. K. Wamsley, and M. J. Kuhar (1981) High affinity GABA receptors-autoradiographic localization. Brain Res. 222: 285 307.

Penney, J. B., H. S. Pan, A. B. Young, K. A. Krey, and G. W. Dauth (1981) Quantitative autoradiography of $\left[{ }^{3} \mathrm{H}\right]$ muscimol binding in rat brain. Science 214: 1036-1038.

Polc, P., E. P. Bonetti, R. Schaffner, and W. Haefely (1982) A threestate model of the benzodiazepine receptor explains the interactions between the benzodiazepine antagonist Ro 15-1788, benzodiazepine tranquillizers, $\beta$-carbolines, and phenobarbitone. Naunyn Schmeidebergs Arch. Pharmacol. 321: 260-264.

Ribak, C. E., J. E. Vaughn, and K. Saito (1978) Immunocytochemical localization of glutamic acid decarboxylase in neuronal somata following colchicine inhibition of axonal transport. Brain Res. 140:315332.

Richards, J. G., H. Möhler, and W. Haefely (1986) Mapping benzodiazepine receptors in the CNS by radiohistochemistry and immunohistochemistry. In Neurology and Neurobiology, vol. 16: Neurohistochemistry: Modern Methods and Applications, P. Panula, $\mathrm{H}$. Päivärinta, and S. Soinila, eds., pp. 629-677, Liss, New York.

Richards, J. G., P. Schoch, P. Häring, B. Takács, and H. Möhler (1987) Resolving $\mathrm{GABA}_{\mathrm{A}}$ /benzodiazepine receptors: Cellular and subcellular localization in the CNS with monoclonal antibodies. J. Neurosci. 7. 1866-1886.
Roberts, E. (1986) GABA: The road to neurotransmitter status. In Benzodiazepine/GABA Receptors and Chloride Channels: Structural and Functional Properties, R. W. Olsen and J. C. Venter, eds., pp. 139, Liss, New York.

Rose, J. (1938) Zur normalen und pathologischen architectonik er ammonsformation. J. Psychol. Neurol. (Leipzig) 49: 156-188.

Schlander, M., G. Thomalske, and M. Frotscher (1987) Fine structure of GABAergic neurons and synapses in the human dentate gyrus. Brain Res. 401: 185-189.

Schmechel, D. E., B. G. Vickrey, D. Fitzpatrick, and R. P. Elde (1984) GABAergic neurons of mammalian cerebral cortex: Widespread subclass defined by somatostatin content. Neurosci. Lett. 47: 227-232.

Schoch, P., and H. Möhler (1983) Purified benzodiazepine receptor retains modulation by GABA. Eur. J. Pharm. 95: 323-324.

Schoch, P., J. G. Richards, P. Häring, B. Takács, C. Stähli, T. Staehelin, W. Haefely, and H. Möhler (1985) Co-localization of GABA ${ }_{A}$ receptors and benzodiazepine receptors in the brain shown by monoclonal antibodies. Nature 314: 168-171.

Seress, L., and C. E. Ribak (1983) GABAergic cells in the dentate gyrus appear to be local circuit and projection neurons. Exp. Brain Res. 50: 173-182.

Sloviter, R. W., and G. Nilaver (1987) Immunocytochemical localization of GABA-, cholecystokinin-, vasoactive intestinal polypeptide-, and somatostatin-like immunoreactivity in the area dentata and hippocampus of the rat. J. Comp. Neurol. 256: 42-60.

Squires, R. F., J. E. Casida, M. Richardson, and E. Saederup (1983) $\left.{ }^{35} \mathrm{~S}\right] t$-butylbicyclophosphorothionate binds with high affinity to brainspecific sites coupled to $\gamma$-aminobutyric acid-A and ion recognition sites. Mol. Pharmacol. 23: 326-336.

Sternberger, L. A. (1979) Immunocytochemistry, 2nd Ed., pp. 104169, Wiley, New York.

Storm-Mathiscn, J. (1977) Localization of transmitter candidates in the brain: The hippocampal formation as a model. Prog. Neurobiol. 8: 119-181.

Study, R. E., and J. L. Barker (1981) Diazepam and (-)pentobarbital: Fluctuation analysis reveals different mechanisms for potentiation of GABA responses in cultured central neurons. Brain Res. 268: 171176.

Tallman, J., and D. Gallager (1985) The GABAergic system: A locus of benzodiazepine action. Annu. Rev. Neurosci. 8: 21-44.

Ticku, M. K., and G. Maksay (1983) Convulsant/depressant site of action at the allosteric benzodiazepine-GABA receptor-ionophore complex. Life Sci. 33: 2363-2375.

Unnerstall, J. R., M. J. Kuhar, D. L. Niehoff, and J. M. Palacios (1981) Benzodiazepine receptors are coupled to a subpopulation of $\gamma$-aminobutyric acid (GABA) receptors: Evidence from a quantitative autoradiographic study. J. Pharmacol. Exp. Ther. 218: 797-804.

Wamsley, J. K., D. R. Gehlert, and R. W. Olsen (1986) The benzodiazepine/barbiturate-sensitive convulsant/GABA receptor/chloride ionophore complex: Autoradiographic localization of individual components. In Benzodiazepine/GABA Receptors and Chloride Channels: Structural and Functional Properties, R. W. Olsen and J. C. Venter, eds., pp. 299-313, Liss, New York. 